\title{
An Empirical Analysis Of Underlying Factors Affecting The Choice Of Accounting Major
}

Abbas Heiat, Montana State University, Billings

Doug Brown, Montana State University, Billings

Debra M. Johnson, (E-mail: djohnson@msubillings.edu), Montana State University, Billings

\begin{abstract}
This study explores the factors that influence a student's choice of major along with students' perceptions of accounting classes and the accounting profession The results indicate that students are most strongly influenced in their choice of major by a genuine interest in the subject matter. This finding is the same regardless of major and gender. Other influential factors include availability of employment, starting pay, and the ability to interact with people. The factor with the least amount of influence on selection of a major is the expected ease of earning a degree.
\end{abstract}

\section{INTRODUCTION}

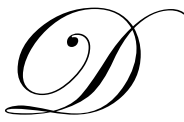

uring the late 90s, there had been a significant decline in the number of accounting graduates. A study conducted by the American Accounting Association, the America Institute of CPAs, the Institute of Management Accountants, and the Big Four accounting firms revealed some alarming statistics about the future of the accounting profession (Swift, 2001). For more than 20 years, the number of students obtaining bachelors and masters degrees in accounting averaged around 60,000 per year. However, the number of accounting degrees awarded in the 1998-1999 year fell to 47,600, a decrease of 20 percent from the 1995-1996 year. The study also reported that the number of students enrolled in accounting programs dropped from 192,000 in 1995-1996 to 148,000 in 1998-1999, a 23-percent decline. In addition, the study found that the number of college students majoring in accounting fell from 4 percent in 1990 to 2 percent in 2000. This decline in the number of accounting graduates came at a time when the job opportunities for accountants were promising. Now, however, starting in 2000, this downward trend appears to have reversed itself. For example, the number of accounting degrees awarded nationwide in 2003 jumped 11 percent from 2002 according to the Wall Street Journal. (Gullapalli, 2004). Accounting now appears to be a top choice of majors by college business students, primarily due to high demand for accountants because of the 2002 Sarbanes-Oxley Act requirements and recent national corporate accounting fraud scandals. According to the U.S. Department of Labor's Occupational Outlook Handbook, employment for accountants is expected to grow between 10 and 20 percent during the period 1998 to 2008. The Job Outlook 2005 survey, conducted by the National Association of Colleges and Employers, currently ranks Accounting as the number one "most in-demand" college major. The largest accounting program in the nation at Florida International University in Miami has reported a 43 percent increase in student enrollment between 2000 and 2003 . One of the nation's biggest producers of accounting undergraduates, the University of Illinois, saw a 66 percent increase in the undergraduate accounting majors from 2001 to 2004. According to the AICPA, in 2003, the number of accounting graduates surged 11 percent over 2002 levels to 49,665 accounting degrees. Accounting also appears to be on the rise for graduate students as well. For example, the University of Michigan reports a 76 percent increase in accounting masters students over the past three years. (Gullapalli, 2004).

Can the decline in the 1990s and the renewed interest in the 2000s be attributed to the current focus on accounting and publicity the profession has received? Do students now perceive accounting as an important profession, critical to our society? Or is it that starting salaries have recently significantly increased? A number of reasons have been advanced, some based on empirical evidence, some based on first-hand experiences, and others 
based on theoretical conclusions. This study explores the factors that influence a student's choice of major along with students' perceptions of accounting classes and the accounting profession in an effort to determine the reasons for college students' interest in accounting as a business major.

\section{REVIEW OF LITERATURE}

There have been several recent important studies of future accounting students and their reasons for entering or not entering the field of accounting (Williams, 2001). In an AICPA commissioned study, the Taylor Research and Consulting Group interviewed 1,000 high school students and 1,000 college students (AICPA Taylor Group Report, 2000). The purpose of the study was to identify: (1) what factors were most important to students in selecting an academic major (2) the perceived positive and negative characteristics of accounting as a major and a profession, and (3) effective marketing approaches to ensure the "best and brightest" continued to enter the profession. The study found that most students were either unaware of the career opportunities available to accounting majors or had limited knowledge of the work performed by accountants. Students also had negative perceptions about the nature of the accounting work itself - viewing it as boring, tedious, and monotonous. Albrecht and Sack interviewed accounting practitioners and educators to determine what factors have affected enrollment in accounting programs (Albrecht and Sach, 2001). They concluded that potential accounting candidates are discouraged by the misconceptions surrounding accountants and the work they do. Citing the Taylor Group report, they stated that misconceptions start in high school with inaccurate definitions of accounting skills as defined on high school aptitude tests, inaccurate and misleading information supplied by high school guidance counselors, and bookkeeping classes disguised as accounting courses.

The Albrecht and Sach study asked participants to identify the "most important reason" students choose to major in accounting today versus five years age. The most frequent response was "starting salaries are lower than in other disciplines, such as information systems." A study conducted by Doran also found that the "most important action" that would attract more high-quality students to the accounting profession would be to "pay higher starting salaries" (Doran, 2001). Now, primarily due to the 2002 Sarbannes-Oxley Act, starting accounting salaries have risen with the increased demand of accounting professionals. For example, according to the 2005 Robert Half Salary Guide, entry level public accountants with large firms can expect to earn $\$ 41,750$ to $\$ 47,000$, a 13.4 percent increase over 2004 salaries. Corporate accounting salaries have also generally increased, particularly in large company internal auditing jobs where 2005 salaries are between $\$ 38,000$ - $\$ 45,000$, a 16.1 percent increase over 2004 .

Accounting education has also received its share of blame for shortages of accounting majors. Technology has made information preparation and dissemination a quick, easy, and inexpensive process. Yet, most introductory accounting classes often focus on the preparation of financial data rather than on its use (Albrecht and Sach, 2001). This approach to accounting education does not expose students to how businesses operate financially (Frieswick, 2000). Some students also feel that accounting courses are simply too hard and require more time than other business classes.

Another often cited and controversial reason for the past decline in the number of accounting graduates is the 150-hour requirement. The 150-hour requirement was adopted by the AICPA in 1988 when an additional 30 hours of college credit beyond the 120-hour undergraduate degree became a prerequisite for those seeking membership in the AICPA beginning in the year 2000 (Boone and Coe, 2002). This action by the accounting profession has prompted most states to adopt the 150-hour education requirement as a condition of CPA licensure. According to Albrecht and Sach, many proponents of the rule now consider it a mistake that increases opportunity costs and forces students to over-specialized. The effect of the 150-hour requirement was the focus of a recent study by Boone and Coe. They concluded that 38 percent of the decline in the number of accounting graduates during the 1990s was due to the 150hour requirement (Boone and Coe, 2002). Apparently now, however, students are not seeing the additional fifth year as a barrier to entering the profession.

A number of other studies have been conducted in order to determine those factors that influence a student's choice of major. Paolillo and Estes conducted one such study to examine those factors underlying students' choice of accounting as a major and career. Their study identified twelve career choice factors influencing accountants and related those factors to the career choices of mechanical engineers, doctors, and attorneys. Survey respondents were 
asked to indicate the relative importance of the twelve factors in their determination of a profession. Availability of employment was the most important of the twelve factors for accountants. Earnings potential, aptitude for the subject matter, and teacher influence also had a greater impact on career-choice for accountants than for the other professional groups. The study was also interested in the timing of the respondents' career choice. Accountants tended to decide on their major during the first two years of college, whereas a large percentage of the mechanical engineers decided on their profession before finishing high school. Because the career-choice factors influencing accountants and engineers were very similar, Paolillo and Estes concluded that the accounting profession was losing access to a substantial number of potential recruits possessing the types of strong analytical skills required by the profession (Paolillo and Estes, 1982).

Cohen and Hanno relied on a social psychological model, known as the theory of planned behavior, to examine students' choice of academic major. They believed that the use of a formal model would help to identify the existence of a theoretical relationship between underlying cognitive constructs and the examined behavior. Once the relationship was established, the model was used to identify specific beliefs that differentiated students who chose to major in accounting from those who had chosen other business majors. An analysis of individual belief statements underlying the constructs indicated that non-accounting majors chose a major other than accounting because they believed accounting was too quantitative and boring. Interestingly enough, both accounting and non-accounting majors felt that the workload in accounting courses would influence choosing a major in a business area other than accounting. Business majors other than accounting majors also had strong negative perceptions of the subject matter of accounting. Non-accounting majors considered success in their introductory courses as a facilitating factor in choosing a business major other than accounting. Thus, the lack of positive experiences in foundation accounting courses negatively influenced accounting as a choice of academic major (Cohen and Hanno, 1993).

Adams, Pryor, and Adams examined the factors that motivate students to select a major. Their study surveyed students in introductory financial accounting classes because of their ability to change majors without significantly delaying their graduation and because of their accessibility for recruitment by accounting faculty. The study relied heavily on the factors used by Paolillo and Estes with several modifications and additions. One significant factor strongly influencing the major selection decision was "genuine interest in the field." Other significant factors strongly influencing major selection in a positive manner were good job opportunities and high earnings potential, also found to be important factors by Paolillo and Estes. Two additional factors were added to the Paolillo and Estes questions to test the notion that the difficulty of the accounting curriculum was a deterrent to the selection of accounting as a major.

Interesting enough, neither "expected ease of earning a degree in this field" or "ability to maintain a high grade-point average in this major" were found to negatively influence students' choice of major. (Adams, Pryor, and Adams, 1994). Hermanson, Hermanson, and Ivancevich felt that business students' perceptions of the accounting profession played an important role in their decision to major or not to major in accounting. In order to understand these perceptions and their influence on choice of an academic major, they conducted a survey of accounting and nonaccounting majors. The survey presented 17 characteristics of the accounting profession divided into five categories: (1) skills needed for success in accounting, (2) short-term economic concerns, (3) long-term economic concerns, (4) non-financial characteristics of the accounting work environment, and (5) social issues. Students were first asked to rate their perception of each characteristic of the accounting profession. Several significant differences were found with regard to students' perceptions of the accounting profession. The accounting majors had more positive views of the employment outlook in accounting, the nature of accounting work, the ability to interact with people, and the prestige or social status of the profession than did the non-accounting majors. The two groups' perceptions of the starting pay in accounting and the difficulty of attaining professional certification did not differ. The accounting majors also perceived greater personal liability for accountants in public practice. The respondents were also asked to indicate the importance of each of the 17 characteristics of the profession on their decision to major or not to major in accounting. Again, there were significant differences between the two groups. For accounting majors, availability of employment and nature of the work were the most important factors influencing their choice of major. For nonaccounting majors, the nature of the work in accounting and the ability to interact with people were the primary influencing factors to not major in accounting. The non-accounting majors apparently did not like the perceived nature of the work in accounting. For accounting majors, the factors that had the least amount of influence on the 
decision to major in accounting were the personal liability of the profession and the difficulty of attaining professional certification. The accounting profession factors that had the least amount of influence on the non-accounting majors were personal liability, prestige, the availability of employment in accounting, and the starting pay in accounting (Hermanson, Hermanson, and Ivancevich, 1995).

Another study conducted by DeZoort, Lord, and Cargile assessed the correspondence between students' and accounting professors' perceptions of the public accounting work environment. The survey respondents included first-term juniors and last-term seniors who were asked to indicate their level of agreement with a number of different statements regarding the public accounting profession. Juniors were more likely than seniors to view public accounting as an interesting profession, and both groups indicated greater agreement than faculty members regarding perceptions that public accounting provided frequent intellectual challenges. Both juniors and seniors also felt that public accounting deserved to be held in high public regard. All groups, students and professors, tended to agree that the public accounting work environment included some menial job responsibilities (DeZoort, Lord, and Cargile, 1997).

The most recent results of an ongoing, longitudinal study of characteristics of accounting students conducted by the Federation of Schools of Accountancy (FSA) found that the reasons students choose to major in accounting had shifted from a previous study conducted in 1995. The percentage of students selecting "availability of jobs" as the most influential factor dropped significantly from 34 percent in 1995 to 24 percent in 2000 . The percentage of students selecting the factors "money/good salaries," "intellectual challenge," and "prestige" remained constant, but the percentage of students selecting accounting as a major because it is "interesting and exciting" actually increased. The study has also been monitoring the timing of academic major selection by accounting students. Although a significant percentage of students first considered an accounting major during high school, this percentage decreased from the 1995 study. The most common year for selecting an accounting major was found to be the sophomore year of college (Nelson, Vendrzyk, Quirin, and Allen, 2002).

\section{DATA AND METHODOLOGY}

A survey (Appendix A) was developed to gather information related to those factors that influence a students' choice of major, the effect the five-year curriculum in accounting had on their decision to major or not major in accounting, and general perceptions of accounting and the public accounting profession itself. In the first section of the survey, respondents were asked to indicate the influence of nine different factors on their selection of a major. The set of nine possible influences on major decision were determined from factors used by Paolillo and Estes Adams,1982, Pryor, and Adams, 1994, and Hermanson, Hermanson, and Ivancevich,1995. The objective was to include those factors that previously have been found to exert a significant influence on major choice decisions.

The respondents were also asked to indicate whether the five-year curriculum in accounting had an influence on their decision to major in accounting. Students were asked to indicate whether the five-year curriculum influenced their decision to major in accounting, influenced their decision not to major in accounting, or had no influence on their choice to major or not major in accounting.

The last section of the survey asked respondents to indicate their level of agreement with nine different statements regarding accounting courses and the public accounting profession. These statements were determined from various perceptions and beliefs about accounting and the accounting profession as previously identified by Cohen and Hanno,1993, Adams, et al.,1994, and Hermanson, et al.,1995.

The survey was distributed in 2003 and 2004 to the students in college of business at Montana State University-Billings. The data was collected during regularly scheduled class periods. The survey informed students that their participation was voluntary. A total of 357 responses were received of which 345 were useable.

Twenty percent of the respondents were accounting majors, 64 percent were business majors other than accounting majors (referred to from now on as other business majors), and 16 percent were non-business majors. The sample also included $67 \%$ female respondents, $33 \%$ male respondents. Students were also asked to indicate at what 
point in time they decided on their declared major. Forty-two percent of the respondents decided on their major before entering college, 12 percent decided their freshman year, 30 percent their sophomore year, and 16 percent their junior year.

\section{FACTORS INFLUENCING SELECTION OF MAJOR}

For each of the nine factors influencing selection of a major, students were asked to rate the extent of the influence ranging from strongly influenced to negatively influenced. A response of "strongly influenced" was given a weight of four, while "negatively influenced" was given a weight of one. The other responses of "moderately influenced" and "no influence" were rated three and two, respectively. The mean ratings for the three different groups of majors are presented in Table 1 and by relative importance as bar charts in Figure 1.

Table 1: Factors influencing selection of major

\begin{tabular}{|l|c|c|c|}
\hline \multicolumn{1}{|c|}{ Factor } & Accounting & Other Business & Non-business \\
\hline Genuine interest in the subject & 3.71 & 3.55 & 3.91 \\
\hline Availability of employment & 3.50 & 3.36 & 3.00 \\
\hline Instructors & 2.43 & 2.36 & 2.46 \\
\hline Ability to interact with people & 2.86 & 2.89 & 3.36 \\
\hline Starting pay & 3.07 & 3.00 & 2.82 \\
\hline Personal liability & 2.57 & 2.57 & 2.73 \\
\hline Prestige or social standing & 2.86 & 2.65 & 3.09 \\
\hline Ability to maintain a high GPA & 2.93 & 2.32 & 2.82 \\
\hline Expected ease of earning a degree & 2.07 & 2.41 & 2.36 \\
\hline
\end{tabular}

\section{Figure 1-Factors Influencing Selection of Majors}

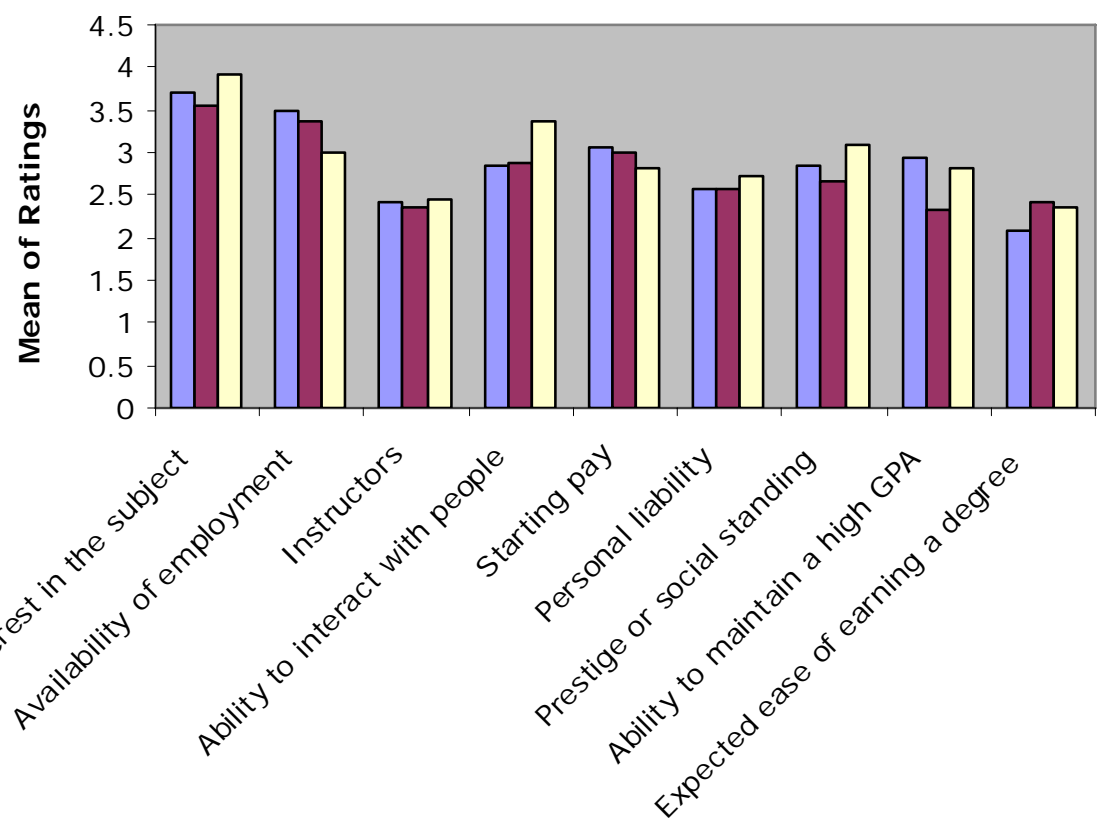

$\square$ Accounting

$\square$ Other Business $\square$ Non-business 
All three groups rated "genuine interest in the subject" as the most important factor influencing their choice of major. This supports previous findings by Adams, et al and Paolillo and Estes. Accounting majors and other business majors also rated availability of employment and starting pay as important factors that influenced their choice of major. These factors were also found to be important determinates of major selection by Paolillo and Estes, Adams, et al, and to a lesser extent, Nelson, et al. Non-business majors were also influenced by availability of employment. Given the current shortages of accounting majors and the projected future needs of the profession, convincing students of the availability of job opportunities should be a relatively straightforward communication task that could be accomplished during introductory accounting classes.

The factors with the least amount of influence on the selection of a major for both accounting majors and all other majors (other business and non-business) were the "expected ease of earning a degree" and "instructors." The lack of influence of the factor "expected ease of earning a degree" indicates that students are not selecting majors based on the perceived rigor of the curriculum. This finding is contrary to the idea that today's students are looking for an easy path to success. Business majors other than accounting also rated the "ability to maintain a high G.P.A." as the factor with the least amount of influence on their choice of major. "Prestige or social standing" had more influence on non-business majors while "personal liability" had little influence on all three groups.

The factors influencing the selection of a major were tested for significance using the following hypothesis:

Null Hypothesis- $\mathbf{H}_{\mathbf{0}}$ : There is no difference between accounting majors, other business majors and non-business majors as to the extent to which each of the nine different factors influenced their selection of major.

Alternative Hypothesis- $\mathbf{H}_{1}$ : There are differences between accounting majors, other business majors, and nonbusiness majors as to the extent to which each of the nine different factors influenced their selection of major.

A one-way ANOVA was used to test the null Hypothesis. A list of the nine factors with their corresponding F-values and P-values is shown in Table 2. The results of the ANOVA indicate that the null hypothesis can be rejected at the .05 level of significance for the factor "ability to maintain a high G.P.A." Thus, for all other factors, there were no significant differences between accounting majors, other business majors and non-business majors regarding the extent to which these factors influenced choice of major.

Table 2: ANOVA to test differences among accounting, other business,and non-business majors

\begin{tabular}{|l|c|c|c|}
\hline \multicolumn{1}{|c|}{ Factors } & F-Value & P-value & \\
\hline Genuine interest in the subject & 2.85 & 0.065 & \\
\hline Availability of employment & 2.30 & 0.108 & \\
\hline Instructors & 0.10 & 0.906 & \\
\hline Ability to interact with people & 2.34 & 0.104 & \\
\hline Starting pay & 0.56 & 0.571 & $* .790$ \\
\hline Personal liability & 0.24 & 0.111 & \\
\hline Prestige or social standing & 2.27 & 0.013 & \\
\hline Ability to maintain a high GPA & 4.67 & 0.269 & \\
\hline Expected ease of earning a degree & 1.34 & & \\
\hline$*$ significant at $\alpha=.05$ & & & \\
\hline
\end{tabular}

A Tukey multiple pair wise comparison procedure was used to determine the differences between means for the factor "ability to maintain a high G.P.A." According to Tuck's method we should reject the null hypothesis that the two population means are equal whenever the confidence interval for the difference in the means does not contain 0 . The results are shown in Table 3. 
Table 3: Pair wise multiple comparisons of the means

\begin{tabular}{|c|c|c|c|}
\hline & Difference Between & Difference Between & Difference Between \\
\hline & $\begin{array}{l}\text { Accounting and } \\
\text { Other Business }\end{array}$ & $\begin{array}{l}\text { Accounting and } \\
\text { Non-business }\end{array}$ & $\begin{array}{l}\text { Non-business and } \\
\text { Other Business }\end{array}$ \\
\hline & $\begin{array}{c}\text { Confidence Interval } \\
95 \%\end{array}$ & $\begin{array}{c}\text { Confidence Interval } \\
95 \%\end{array}$ & $\begin{array}{c}\text { Confidence Interval } \\
95 \%\end{array}$ \\
\hline $\begin{array}{c}\text { Ability to maintain a high } \\
\text { G.P.A. }\end{array}$ & 0.0663 to 1.1545 & -0.6040 to 0.8248 & -0.0977 to 1.0977 \\
\hline
\end{tabular}

The results of the Tukey multiple comparison procedure indicate that significant differences exist at the .05 level of significance between accounting majors and other business majors regarding the influence the factor "ability to maintain a high G.P.A." It appears that accounting majors, while somewhat influenced by this factor, must believe they have the ability to maintain a strong G.P.A. in their chosen major. Since other business majors rated this factor as having the least amount of influence on their choice of major, one can conclude that other business majors are not deterred from a major just because they may not be able to maintain "good grades."

\section{EFFECT OF THE 5-YEAR REQUIREMENT}

The second section of the survey asked respondents to indicate whether the five-year curriculum in accounting had an influence on their decision to major in accounting, to not major in accounting, or had no influence one way or the other. Interestingly enough, only 17 percent of the respondents indicated that the extra year influenced their decision to not major in accounting. Seventy-one percent of the respondents indicated that the 5-year curriculum had no effect on their choice of major.

Respondents were also asked whether the cost of the extra year had an influence on their decision to major in accounting one way or other. Twenty-six percent of the respondents indicated that cost did influence their decision to not major in accounting; however, 64 percent indicated that cost had no influence on their choice of major.

These findings tend to dispute the prevailing notion that the 150 hour requirement is the reason students are not attracted to accounting. Since a significant portion of today's students plan on attending graduate school, the thought of an additional year of education appears not be a deterrent in the selection of a particular major.

\section{PERCEPTIONS OF ACCOUNTING AND THE ACCOUNTING PROFESSION}

The last section of the survey asked respondents to indicate their level of agreement with nine different statements regarding accounting courses and the public accounting profession. The possible responses and their respective weights are as follows: strongly agree (six), agree (five), neutral (four), disagree (three), strongly disagree (two), and no opinion (one). The mean ratings for the three different groups of majors are presented in Table 4 and by relative level of agreement as in Figure 2.

Table 4: Perceptions about accounting courses and accounting profession

\begin{tabular}{|l|c|c|c|}
\hline \multicolumn{1}{|c|}{ Factors } & Accounting & Other Business & Non-business \\
\hline Interesting Profession & 5.21 & 3.73 & 3.73 \\
\hline Intellectual Challenges & 5.36 & 4.25 & 2.09 \\
\hline Menial Responsibilities & 4.21 & 3.16 & 3.91 \\
\hline Different Careers & 5.21 & 4.26 & 4.00 \\
\hline Interact People & 5.36 & 4.18 & 4.73 \\
\hline High Regard & 5.36 & 4.32 & 3.46 \\
\hline Course Work & 2.79 & 3.36 & 3.09 \\
\hline Interesting Courses & 4.57 & 3.23 & 3.27 \\
\hline Comparable Money & 4.29 & 3.68 & \\
\hline
\end{tabular}




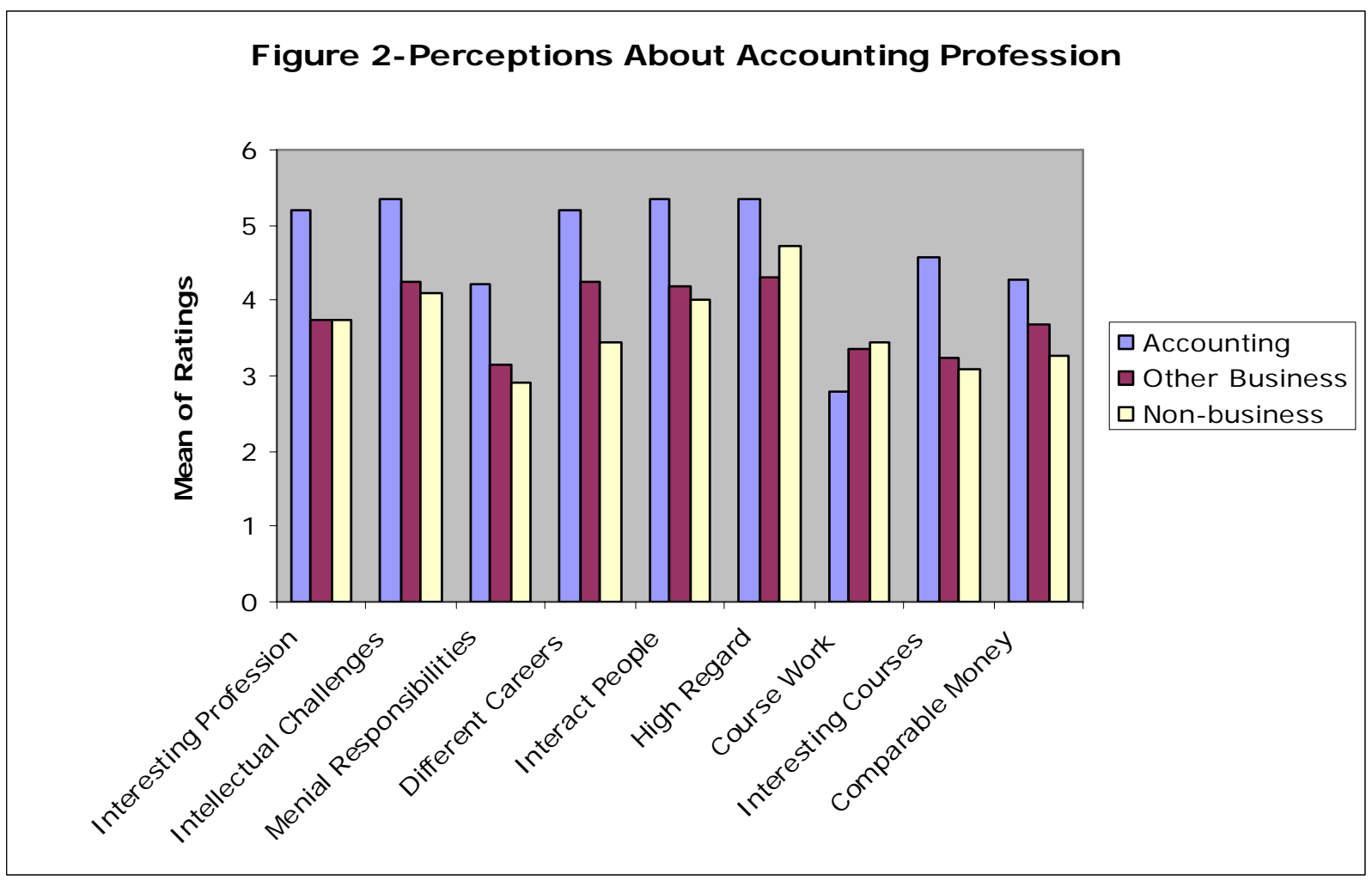

Overall, accounting students feel that public accounting provides frequent intellectual challenges, the ability to work with people, and that the profession deserves to be held in high regard by the general public. These findings are consistent with those of Hermanson, et al.(1995), in that accounting majors have positive views regarding the accounting profession. Non-business majors also feel that the public accounting profession deserves to be held in high regard; however, they do not agree with this statement as strongly as the accounting majors. Accounting majors view public accounting as an interesting profession and feel they have a good understanding of the different careers available to an accountant. The accounting majors also tend to view accounting classes as interesting, but disagree that they do not require any more work than other business classes. They are more neutral regarding the statement that "accounting majors make as much money as other business graduates" and that "public accounting involves a minimal amount of menial job responsibilities."

Other business majors also feel that public accounting provides frequent intellectual challenges and the ability to work with people. Again, however, they do not agree with these statements as strongly as the accounting majors. Other business majors feel they understand the different careers available to accounting majors, but are neutral in their beliefs that public accounting is an interesting profession and provides comparable pay. They disagree that public accounting involves a minimal amount of menial job responsibilities. They also disagree with the statements that "accounting courses are interesting as other business classes" and "accounting courses require no more work than other business classes."

Non-business majors are neutral in their beliefs that public accounting is an interesting profession that provides frequent intellectual challenges. They do not have a good understanding of the different careers available to someone with an accounting degree but disagree that public accounting involves a minimal amount of menial job responsibilities. They also disagree that public accounting provides comparable pay with other business majors. Their impressions of accounting classes and the amount of work they require mirror those of other business majors. 
The perceptions of accounting and the public accounting profession were tested for significance using the following hypothesis:

Null Hypothesis- $\mathbf{H}_{0}$ : There is no difference between accounting majors, other business majors and non-business majors regarding their perceptions of accounting and the public accounting profession.

Alternative Hypothesis- $\mathbf{H}_{\mathbf{1}}$ : There are differences between accounting majors, other business majors, and nonbusiness majors regarding their perceptions of accounting and the public accounting profession.

A one-way ANOVA was used to test the null hypothesis. A list of the different perceptions with their corresponding F-values and P-values is shown in Table 5. The results of the ANOVA indicate that the null hypothesis can be rejected at the .05 level of significance for all statements except "accounting courses require no more work than other business classes" and "accounting graduates make as much money as other business graduates."

Table 5: ANOVA to test differences among accounting, other business, and non-business majors

\begin{tabular}{|l|c|c|c|}
\hline \multicolumn{1}{|c|}{ Factors } & F-Value & P-value & $*$ \\
\hline Interesting profession & 9.78 & 0.000 & $*$ \\
\hline Intellectual challenges & 3.41 & 0.039 & $*$ \\
\hline Menial responsibilities & 4.37 & 0.017 & $*$ \\
\hline Different careers & 7.47 & 0.001 & $*$ \\
\hline Interact with people & 4.45 & 0.015 & $* .022$ \\
\hline High regard & 4.07 & 0.289 & $*$ \\
\hline Course work & 1.27 & 0.004 & $* .307$ \\
\hline Interesting classes & 6.12 & & \\
\hline Comparable money & 1.20 & & \\
\hline$*$ significant at $\alpha=.05$ & & & \\
\hline
\end{tabular}

The results presented in Table 5 indicate significant differences among the groups in seven of the nine different perceptions about accounting classes and the accounting profession.

A Tukey multiple comparison procedure was used to determine the differences between means for the statements "public accounting is an interesting profession," "public accounting provides frequent intellectual challenges," "public accounting involves a minimal amount of menial job responsibilities," "I understand the different careers available to an individual with an accounting degree," "public accounting provides opportunities to interact with other people," "the public accounting profession deserves to be held in high regard by the general public," and "accounting courses are as interesting as other business classes." The results are shown in Table 6.

Table 6: Pair wise multiple comparisons of the means

\begin{tabular}{|l|c|c|c|}
\hline \multicolumn{1}{|c|}{ Factors } & $\begin{array}{c}\text { Difference Between } \\
\text { Accounting and Other } \\
\text { Business }\end{array}$ & $\begin{array}{c}\text { Difference Between } \\
\text { Accounting and Non-business }\end{array}$ & $\begin{array}{c}\text { Difference Between Non- } \\
\text { business and Other Business }\end{array}$ \\
\hline & Confidence Interval 95\% & Confidence Interval $95 \%$ & Confidence Interval 95\% \\
\hline Interesting Profession & 0.661 to 2.313 & 0.402 to 2.572 & -0.908 to 0.908 \\
\hline $\begin{array}{l}\text { Intellectual } \\
\text { Challenges }\end{array}$ & 0.027 to 2.187 & -0.152 to 2.685 & -1.346 to 1.028 \\
\hline $\begin{array}{l}\text { Menial } \\
\text { Responsibilities }\end{array}$ & 0.118 to 1.992 & 0.075 to 2.536 & -1.280 to 0.780 \\
\hline Different Careers & 0.114 to 1.803 & 0.654 to 2.866 & -1.729 to 0.126 \\
\hline Interact People & 0.168 to 2.183 & 0.035 to 2.680 & -1.288 to 0.925 \\
\hline High Regard & 0.157 to 1.921 & -0.529 to 1.788 & -0.560 to 1.378 \\
\hline Interesting Courses & 0.377 to 2.311 & 0.211 to 2.750 & -1.199 to 0.926 \\
\hline
\end{tabular}


The results of the Tukey multiple comparison procedure indicate that significant differences exist at the .05 level of significance between accounting majors and other business majors for all seven of the belief statements. Significant differences also exist between accounting majors and non-business majors regarding "interesting profession," "menial responsibilities," "understanding of the different careers," "interacting with people," and "interesting courses" statements. The results of these tests indicate that while accounting majors view their classes and the accounting profession in a very positive manner, other business and non-business majors have some negative perceptions and beliefs.

Both other business majors and non-business majors show significant differences from accounting majors regarding their understanding of the different careers available to an individual with an accounting degree. This finding tends to suggest that students may develop a greater awareness of different opportunities in a particular field once they "commit" to that field by selecting it as a major. It is also likely that students who have a genuine interest in a particular major are more inclined to seek information regarding possible careers in that major from a number of different sources.

Accounting majors also perceive public accounting to be a much more interesting profession than other business majors and non-business majors. Other business majors and non-business majors view public accounting as a career involving menial job responsibilities and having limited interactions with people. Other business majors also feel that public accounting does not provide frequent intellectual challenges. These findings support the conclusions reached by the Taylor Research Group and Albrecht and Sach that public accounting still suffers from an image problem. Accountants are still often portrayed as "green visored bean counters" who sit in offices crunching numbers. This view of accountants is also coupled with the perception by other business majors and non-business majors that accounting courses are less interesting than other business classes.

In light of these findings, it is important for practitioners to take active steps to help change any incorrect perceptions of accounting. Personal stories or examples that illustrate the dynamic nature of accounting careers, the need for strong interpersonal skills, and the importance of creative problem-solving skills should help to address the negative perceptions of accountants and accounting. Instructors also need to structure accounting classes so that students do not view them as merely "bookkeeping" classes. Students need to realize the importance of accounting in an overall business setting as a source of information used to make strategic business decisions.

Other business majors differ in their views regarding the statement "the public accounting profession deserves to be held in high regard by the general public." It is very possible this perception has been fueled by the recent accounting scandals. Although the negative press from these scandals may impact students' perceptions of the accounting profession, it also points out the need for accounting graduates to consider the importance of ethics training in addition to the other skills required to succeed in the profession.

\section{Gender Differences}

The last topic of our research explores the possibility of gender differences. The mean ratings for males and females regarding each of the nine factors influencing selection of a major are presented in Table 7 and by relative importance in Figure 3.

Table 7: Gender differences regarding accounting Courses \& profession

\begin{tabular}{|l|c|c|}
\hline \multicolumn{1}{|c|}{ Factor } & Males & Females \\
\hline Genuine interest in the subject & 3.71 & 3.60 \\
\hline Availability of employment & 3.63 & 2.16 \\
\hline Instructors & 2.50 & 3.30 \\
\hline Ability to interact with people & 2.83 & 2.88 \\
\hline Starting pay & 3.17 & 2.72 \\
\hline Personal liability & 2.42 & 2.79 \\
\hline Prestige or social standing & 2.75 & 2.58 \\
\hline Ability to maintain a high GPA & 2.46 & 2.42 \\
\hline Expected ease of earning a degree & 2.21 & \\
\hline
\end{tabular}




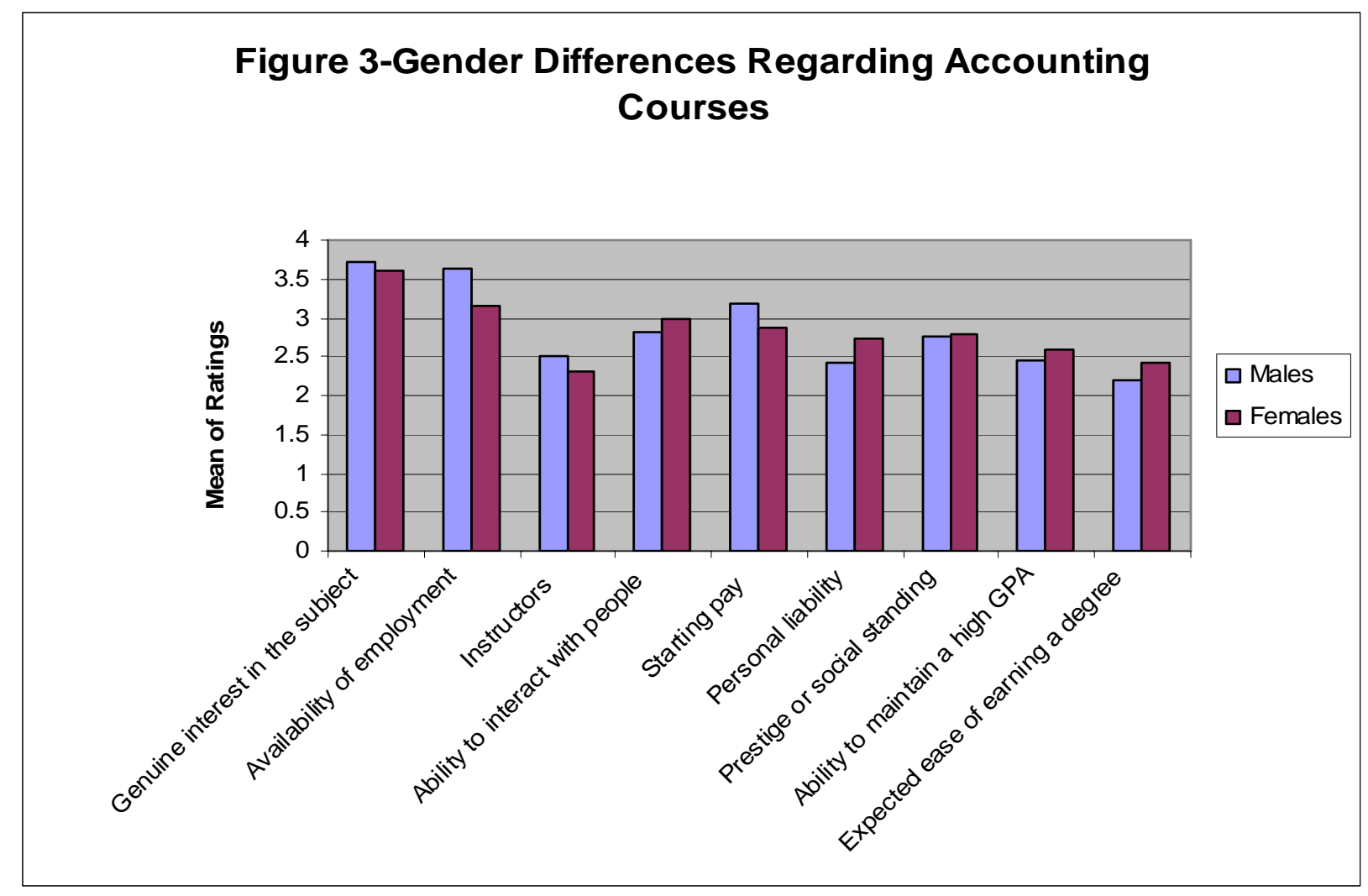

Males and females both rated "genuine interest in the subject" as the factor having the most influence on their choice of major. Both groups were influenced by "availability of employment," "starting pay," and the "ability to interact with people." "Expected ease of earning a degree" and the "ability to maintain a high G.P.A." had little influence on either group.

The factors influencing the selection of a major were tested for significant using the following hypothesis:

Null Hypothesis- $\mathbf{H}_{0}$ : There is no difference between males and females as to the extent to which each of the nine different factors influenced their selection of major.

Alternative Hypothesis- $\mathrm{H}_{1}$ : There are differences between males and females as to the extent to which each of the nine different factors influenced their selection of major.

A two-tailed t-test was used to test the null hypothesis. A list of the nine factors with their corresponding tvalues and $\mathrm{P}$-values is shown in Table 8.

The results of the t-test indicate that the null hypothesis can only be rejected at the .05 level of significance for the factor "availability of employment." Although both males and females are influenced in their choice of major by the availability of employment, males are more strongly influenced than females as indicated by the relative means for this factor (males 3.63 and females 3.16). Although the explanation sounds trite, our society still tends to look upon males as the primary source of support in a family. Women leave the work force more often than men in order to bear and raise children. It is possible that the difference in significance attached to this factor reflects the influence of our society's attitude. 
Table 8: Two-tailed t-test for comparing gender differences regarding accounting courses \& profession

\begin{tabular}{|l|c|c|c|}
\hline \multicolumn{1}{|c|}{ Factors } & t-Value & P-value & 0.4000 \\
\hline Genuine interest in the subject & 0.84 & 0.0024 & $*$ \\
\hline Availability of employment & 3.16 & 0.2700 & \\
\hline Instructors & 1.12 & 0.3500 & \\
\hline Ability to interact with people & -0.94 & 0.0710 & \\
\hline Starting pay & 1.84 & 0.0760 & \\
\hline Personal liability & -1.80 & 0.8300 & \\
\hline Prestige or social standing & -0.21 & 0.5300 & \\
\hline Ability to maintain a high GPA & -0.63 & 0.2200 & \\
\hline Expected ease of earning a degree & -1.25 & & \\
\hline$*$ significant at $\alpha=.05$ & & & \\
\hline
\end{tabular}

The mean ratings for males and females regarding their perceptions of public accounting and accounting classes are presented in Table 9 and by relative level of agreement in Figure 4.

Table 9: Gender differences regarding perceptions of accounting courses \& profession

\begin{tabular}{|l|c|c|}
\hline \multicolumn{1}{|c|}{ Factors } & Males & Females \\
\hline Interesting Profession & 4.21 & 3.95 \\
\hline Intellectual Challenges & 4.88 & 4.26 \\
\hline Menial Responsibilities & 3.46 & 3.14 \\
\hline Different Careers & 4.65 & 4.14 \\
\hline Interact People & 4.79 & 4.21 \\
\hline High Regard & 4.96 & 4.37 \\
\hline Course Work & 3.25 & 3.19 \\
\hline Interesting Courses & 3.88 & 3.26 \\
\hline Comparable Money & 3.92 & 3.58 \\
\hline
\end{tabular}

Males and females indicated the highest level of agreement for the same four statements concerning high regard for the profession, intellectual challenges provided by the profession, the ability to interact with people, and an understanding of the different careers. However, males agreed with these statements more than females. Males and females also indicated the lowest level of agreement with the same four statements regarding menial job responsibilities, course work, interesting classes, and comparable money. Both groups were neutral regarding their perceptions of public accounting as an interesting profession.

The perceptions of accounting and the public accounting profession were tested for significant using the following hypothesis:

Null Hypothesis- $\mathbf{H}_{\mathbf{0}}$ : There is no difference between males and females regarding their perceptions of accounting courses and the public accounting profession.

Alternative Hypothesis- $\mathbf{H}_{1}$ : There are differences between males and females regarding their perceptions of accounting courses and the public accounting profession.

A two-tailed t-test was used to test the null hypothesis. A list of the different perceptions with their corresponding t-values and P-values is shown in Table 10. 
The results of the t-test indicate that there are no significant differences between males and females at the .05 level of significance regarding their perceptions of the public accounting profession and accounting classes. Therefore, the null hypothesis cannot be rejected.

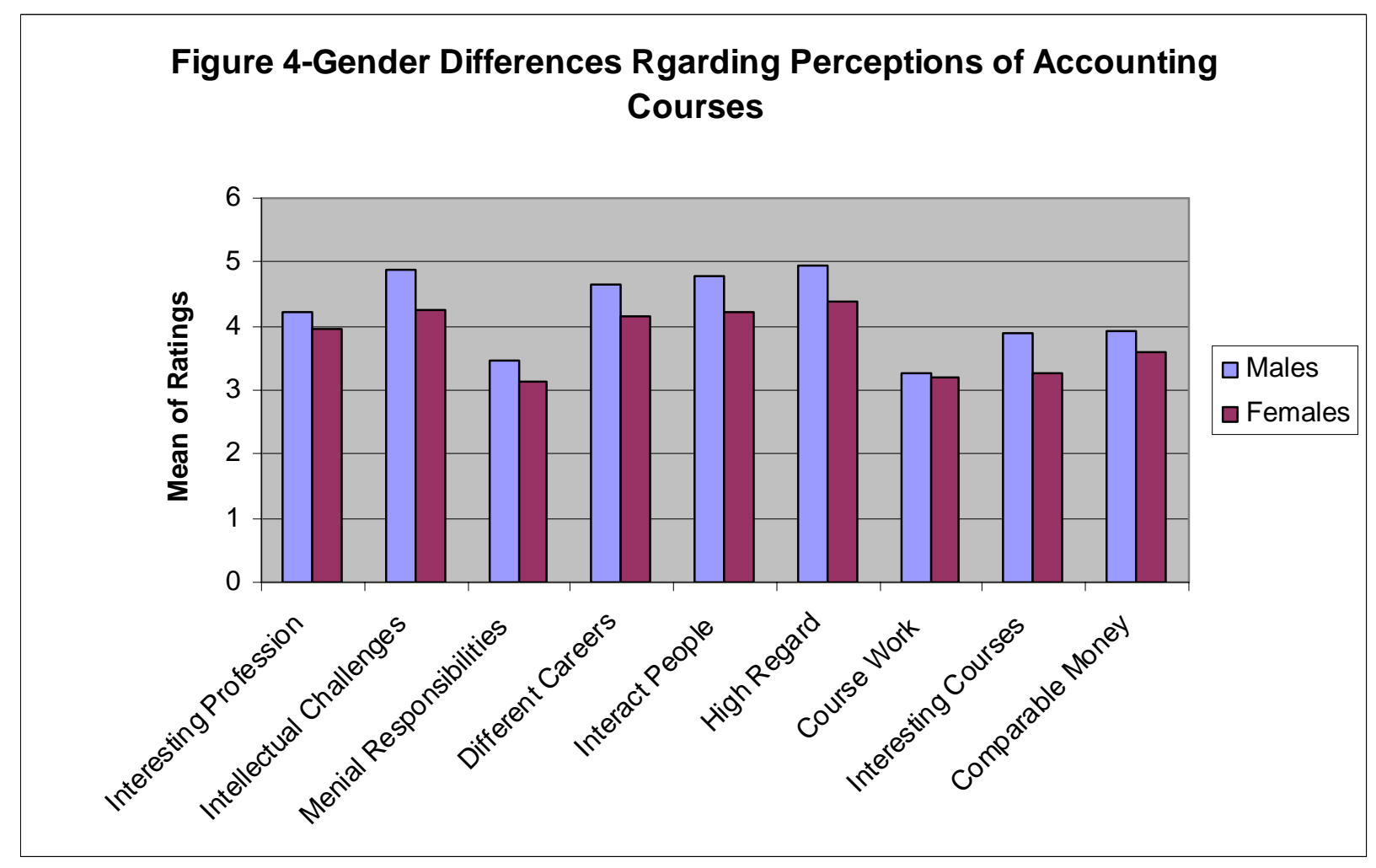

Table 10: Two-tailed t-test for comparing gender differences regarding perceptions of accounting courses \& profession

\begin{tabular}{|l|c|c|}
\hline \multicolumn{1}{|c|}{ Factor } & t-Value & P-value \\
\hline Interesting profession & 0.80 & 0.430 \\
\hline Intellectual challenges & 1.63 & 0.110 \\
\hline Menial responsibilities & 0.98 & 0.330 \\
\hline Different careers & 1.58 & 0.120 \\
\hline Interact with people & 1.62 & 0.110 \\
\hline High regard & 1.86 & 0.067 \\
\hline Course work & 0.20 & 0.840 \\
\hline Interesting classes & 1.75 & 0.084 \\
\hline Comparable money & 0.78 & 0.440 \\
\hline
\end{tabular}

\section{CONCLUSIONS}

The purpose of this study was to determine some of the underlying causes that affect the selection of accounting as a major. To accomplish this task, students were surveyed to determine what factors influence their choice of major, the effect the five-year curriculum in accounting has on their decision to major or not major in accounting, and general perceptions of accounting and the public accounting profession itself.

Students are most strongly influenced in their choice of major by a genuine interest in the subject matter. This finding is the same regardless of major and gender. Other influential factors include availability of employment, 
starting pay, and the ability to interact with people. The factor with the least amount of influence on selection of a major is the expected ease of earning a degree. Thus, the perceived difficulty of obtaining a particular major is not a negative influence if the student is truly interested in the subject matter of that major, and perceives that he or she will be rewarded with good paying job opportunities after graduation.

Significant differences were found to exist between accounting majors and other business majors regarding the influence of the factor "ability to maintain a high G.P.A." has on the choice of a major. Other business majors rated the "ability to maintain a high G.P.A." as the factor with the least amount of influence. This tends to support the conclusion that genuine interest in the subject matter of a particular major is more important than selecting an "easy" major in which the student has no real interest but can get better grades.

Significant differences were found to exist between males and females regarding the influence of the factor "availability of employment." Both males and females were influenced by this factor; however, males were more strongly influenced than females.

The majority of student responses indicate that the five-year requirement in the accounting curriculum has no influence on their choice of major. Although many accountants believe this requirement is responsible for the lack of interest in accounting as a major, it appears not to be. Although a higher percentage of students indicated that the cost of an additional year of school influenced their decision to not major in accounting, the overwhelming majority of students did not feel that it affected their decision one way of the other. It appears that factors other than a five-year curriculum are more important in the selection or rejection of a accounting as a major.

Several significant differences were observed between the perceptions of accounting majors and other majors regarding their beliefs and attitudes about accounting and the public accounting profession. The results indicate that non-accounting majors may choose a major other than accounting because they lack an understanding of the different careers available to someone with an accounting degree. This lack of understanding does not help alleviate the image of an accountant as someone who sits alone in an office performing menial, boring, and uninteresting tasks. Accounting practitioners in particular need to become more active in promoting the positive aspects of the profession if they wish to continue to attract students to the profession. Due to the proliferation of computerized bookkeeping software in recent years, accountants no longer perform the relatively tedious and low level task of manually "keeping the books." Instead, even small local firms spend a large amount of their time providing services as business advisors, human resource consultants, litigation experts, computer consultants, and financial planners.

Because non-accounting majors tend to view accounting classes as significantly less interesting than other business classes, accounting instructors need to insure that accounting classes focus on the uses of accounting information as a strategic business resource.

This study also found that a large majority of students selected their major before entering college (41 percent) or during their sophomore year $(30$ percent). These findings illustrate the importance of providing information to students during high school or early in college about the opportunities and benefits associated with a particular major such as accounting.

As with most studies, certain limitations may affect the interpretation of the results. All subjects in the study were from MSU-Billings. Most of the survey respondents were business majors other than accounting majors, women, and upper classmen (juniors and seniors). A sample with a more equal distribution of demographics may have yielded different results. Also, MSU-Billings is the smallest of the three major universities in the State of Montana and has an older student body. A sample including students from the other two major universities might result in different responses.

Although this study identifies a number of perceptions and beliefs about the accounting profession that facilitate a choice of major other than accounting, it does not address how these beliefs and perceptions are formed. This lack of understanding could form the basis for future research. Future research could also determine what steps are currently being taken by accounting practitioners and educators to attract students into the profession and analyze the effectiveness of their efforts. 
The results of this study validate some of the conclusions reached by the Taylor Research Group and Albrecht and Sach regarding perceptions of the accounting profession as an uninteresting tedious profession devoid of intellectual challenges and interactions with people. In order to attract future students to the profession, practitioners and educators alike need to educate students about the many opportunities and life-long challenges that exist for students who decide to pursue a major in accounting.

\section{REFERENCES}

1. Adams, S. J., L J. Pryor, and S. L. Adams. Attraction and retention of high -aptitude students in accounting: An exploratory longitudinal study. Issues in Accounting Education (August 1994). Pp. 45-58.

2. Albrecht, W.S., and R.J. Sach, The Perilous Future of Accounting Education, The CPA Journal (March 2001), pp.17-23.

3. American Institute of Certified Public Accountants (AICPA), Student and Academic Research Study, Taylor Research and Consulting Group (July 2000).

4. Boone, J.P., and T.L. Coe, The 150-Hour Requirement and Changes in the Supply of Accounting Undergraduates: Evidence from a Quasi-Experiment, Issues in Accounting Education (August 2002), pp. 253-268.

5. Cohen, J., and D.M. Hanno, An Analysis of Underlying Constructs Affecting the Choice of Accounting Major, Issues in Accounting Education (Fall 1993), pp. 219-238.

6. DeZoort, F.T., A.T. Lord, and B.R. Cargile, A Comparison of Accounting Professors' and Students' Perceptions of the Public Accounting Work Environment, Issues in Accounting Education (Fall 1997), pp. 281-298.

7. Doran, D.T., Concern for the Future of the Accounting Profession, The CPA Journal (May 2001), p.11.

8. Frieswick, C, Where Have all the CPAs Gone? CFO, (December 2000), pp. 101-104.

9. Hermanson, D.R., R. H. Hermanson, and S.H. Ivancevich, Are America's Top Business Students Steering Clear of Accounting? The Ohio CPA Journal, (April 1995)

10. Nelson, I.T., V.P. Vendrzyk, J.J. Quirin, and R.D. Allen, No, the Sky is not Falling: Evidence of Accounting Student Characteristics at FSA Schools, 1995-2000, Issues in Accounting Education (August 2002), Vol. 17, No.3.

11. Paolillo, J.F.P., and R.W. Estes, An Empirical Analysis of Career Choice Factors Among Accountants, Attorneys, Engineers, and Physicians, Accounting Review (October 1982), pp. 785-793.

12. Swift, S., Students Shortchange Accounting, Indianapolis Business Journal (2001).

13. U.S. Department of Labor, Bureau of Labor Statistics, Occupational Outlook Handbook, 2000-2001 edition.

14. Williams, A.S., The Acounting Profession's Labor Crisis: How We Got Here, The Practicing CPA (March 2001), Vol 25 No.3.

\section{APPENDIX A}

Thank you in advance for completing the voluntary survey below. Your participation is very much appreciated. All responses to this survey will be confidential. Please return completed survey to Dr. "name removed" COB Room 106.

1. What is your declared major? If you have more than one declared major, please indicate your $1^{\text {st }}$ choice in a major. (Check one.)

Accounting major

Business major other than accounting

Nonbusiness major

Have not declared a major

2. If you have a declared major, when did you decide on this major? If you have no declared major, please skip this question and go to question 3 .

Before entering college

Freshman year of college

Sophmore year of college

Junior year of college

Senior year of college 
Please rate the extent to which each factor did (will) influence your selection of a major.

Genuine interest in the subject

Availability of employment

Instructors

Ability to interact with people

Starting pay

Personal liability

Prestige or social standing

Ability to maintain a high GPA

Expected ease of earning a degree

$\begin{array}{cc}\begin{array}{c}\text { Strongly } \\ \text { Influenced } \\ \boldsymbol{\nabla}\end{array} & \begin{array}{c}\text { Moderately } \\ \text { Influenced }\end{array} \\ 4 & \boldsymbol{\nabla} \\ 4 & 3 \\ 4 & 3 \\ 4 & 3 \\ 4 & 3 \\ 4 & 3 \\ 4 & 3 \\ 4 & 3 \\ 4 & 3 \\ & 3\end{array}$

$\begin{array}{cc}\begin{array}{c}\text { No } \\ \text { Influence }\end{array} & \begin{array}{c}\text { Negatively } \\ \text { Influenced }\end{array} \\ 2 & \boldsymbol{\nabla} \\ 2 & 1 \\ 2 & 1 \\ 2 & 1 \\ 2 & 1 \\ 2 & 1 \\ 2 & 1 \\ 2 & 1 \\ 2 & 1 \\ & 1\end{array}$

4. Did (Would) the 5-year curriculum in accounting influence your decision to major in accounting one way or the other? (Check one.)

Did (would) influence my decision to major in accounting

Did (would) influence my decision NOT to major in accounting

No influence one way or the other

5. Did (Would) the cost of the additional $5^{\text {th }}$ year in the accounting curriculum influence your decision to major in accounting one way or the other?

Did (would) influence my decision to major in accounting

Did (would) influence my decision NOT to major in accounting

No influence one way or the other

6. Please circle your level of agreement with each of the following statements:

a. Public accounting is an interesting profession.

Strongly agree Agree Neutral Disagree Strongly Disagree No Opinion

b. Public accounting provides frequent intellectual challenges.

Strongly Agree Agree Neutral Disagree Strongly Disagree No Opinion

c. Public accounting involves a minimal amount of menial job responsibilities.

Strongly Agree Agree Neutral Disagree Strongly Disagree No Opinion

d. I understand the different careers available to an individual with an accounting degree. Strongly Agree Agree Neutral Disagree Strongly Disagree No Opinion

e. Public accounting provides opportunities to interact with other people. Strongly Agree Agree Neutral Disagree Strongly Disagree No Opinion

f. The public accounting profession deserves to be held in high regard by the general public. Strongly Agree Agree Neutral Disagree Strongly Disagree No Opinion

g. Accounting courses require no more work than other business classes. Strongly Agree Agree Neutral Disagree Strongly Disagree No Opinion

h. Accounting courses are as interesting as other business classes. Strongly Agree Agree Neutral Disagree Strongly Disagree No Opinion

i. Accounting graduates make as much money as other business graduates. Strongly Agree Agree Neutral Disagree Strongly Disagree No Opinion

Demographics (for classification purposes only):

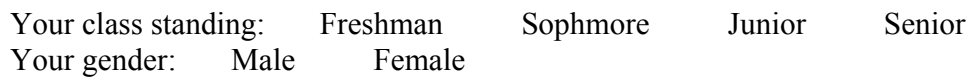

